\title{
Confirmation of the localization of the human recombination activating gene 1 (RAG1) to chromosome 11 p13
}

\author{
Klaus Schwarz ${ }^{1}$, Horst Hameister ${ }^{2}$, Manfred Gessler ${ }^{3}$, Karl-Heinz Grzeschik ${ }^{3}$, Thomas E. Hansen-Hagge ${ }^{1}$, \\ Claus R. Bartram 1 \\ ' Sektion Molekularbiologie, Kinderklinik II, Universität Ulm, Prittwitzstrasse 43, D-89075 Ulm, Germany \\ ${ }^{2}$ Abteilung für Klinische Genetik, Universität Ulm, Frauenstrasse 29, D-89073 Ulm, Germany \\ ${ }^{3}$ Institut für Humangenetik, Universităt Marburg, Bahnhofstrasse 7a, D-35037, Marburg, Germany \\ Received: 17 May 1993 / Revised: 11 August 1993
}

\begin{abstract}
The human recombination activating gene 1 (RAG1) has previously been mapped to chromosomes $14 \mathrm{q}$ and $11 \mathrm{p}$. Here we confirm the chromosome 11 assignment by two independent approaches: autoradiographic and fluorescence in situ hybridization to metaphase spreads and analysis of human-hamster somatic cell hybrid DNA by the polymerase chain reaction (PCR) and Southern blotting. Our results unequivocally localize RAG1 to 11p13.
\end{abstract}

\section{Introduction}

During lymphocyte development the complete variable domain of immunoglobulins and T-cell receptors is generated by a site-specific multistep process recombining so called variable (V), diversity (D), or joining (J) elements (for reviews see Blackwell and Alt 1988; Davis 1988). Two adjacent lymphocyte specific genes, RAG1 and RAG2, have been isolated, which are functionally correlated to V(D)J recombinase activity (Oettinger et al. 1990; Schatz et al. 1989). Recently, RAG1 has been mapped to two different chromosomes, namely $14 \mathrm{q} 21.3-\mathrm{q} 22.2$ (Blanquet et al. 1992) and 11(p12-p13) (Oettinger et al. 1992; Ichihara et al. 1992). Since we are interested in the molecular characterization of human severe combined immunodeficiency disease (SCID), we isolated the human RAG genes and localized RAG1 by different methods.

\section{Materials and methods}

A probe for human RAG1 was prepared by the polymerase chain reaction (PCR) using primers based on published sequences (Schatz et al. 1989). A pair of primers [RAG1/1, 5'-GACATGGAAGAAGACATCTTGGAAGG-3' $(1827-1852)$ and RAG1/2,

Correspondence to: K. Schwarz
5'AGCCCTCAATGCAACCCAGAGG-3' (3309-3288)] amplified a fragment of $1,482 \mathrm{bp}$. The PCR conditions were as published by Saiki et al. (1988). The amplification conditions consisted of 35 cycles of denaturation at $94^{\circ} \mathrm{C}$ for $1 \mathrm{~min}$, annealing at $56^{\circ} \mathrm{C}$ for $1 \mathrm{~min}$ and extension at $72^{\circ} \mathrm{C}$ for $1.5 \mathrm{~min}$ followed by a $10-\min 72^{\circ} \mathrm{C}$ extension step after the last cycle. The identity of the fragment was confirmed by hybridization to the oligonucleotide RAG1/3 (5'AAACTCAATTGCAAAAACCAA-3') under stringent conditions. The 1,482-bp fragment was used to screen a size selected (15 to 20-kb), partially Sau3a digested EMBL 3 human genomic library. One clone (RAG 1;3) was used to subclone a 5 kb BamHI-Sall fragment into pT7T3U18 (Pharmacia). This fragment includes all of the translated part of RAG1 as well as part of the first intron. In addition, a 2.5-kb EcoNI-HindIII fragment containing only coding sequences was subcloned. Both subclones were confirmed by sequencing.

In situ hybridization was done as previously published (Perry and Wolff 1974; Kunze et al. 1989). For non-radioactive in situ hybridization we followed the procedure of Lichter et al. (1990). Briefly, the $20-\mathrm{kb}$ insert of phage RAGl;3 was nick translated with biotin-11-dCTP. $100 \mathrm{ng}$ of labeled DNA plus cot-1 DNA (Bethesda Research Laboratories, BRL) and herring sperm DNA (50 and $500 \mu \mathrm{g} / \mathrm{ml}$ final concentration, respectively) were used in $20 \mu l$ of hybridization mix per slide. After extensive washing the biotin labeled DNA was detected via fluorescein isothiocyanate (FITC)-avidin. The signal was amplified by binding of biotinylated anti-avidin and a second FITC-avidin detection step. Metaphases were counterstained with 4;6-diamidino-2-phenylindole (DAPI) propidium iodide and photographed on Kodak Ektachrome 400 film.

\section{Results and discussion}

Metaphases were prepared according to standard techniques from human lymphocyte cultures. The cultures were labeled with bromodeoxyuridine to allow for fluorochrome-photolysis-Giemsa (FPG) banding analysis (Perry and Wolff 1974). The procedure for in situ hybridization with ${ }^{3} \mathrm{H}$-labeled probes was exactly as described previously (Kunze et al. 1989). After in situ hybridization with a plasmid containing the 5-kb BamHI-Sall, 16 metaphases 

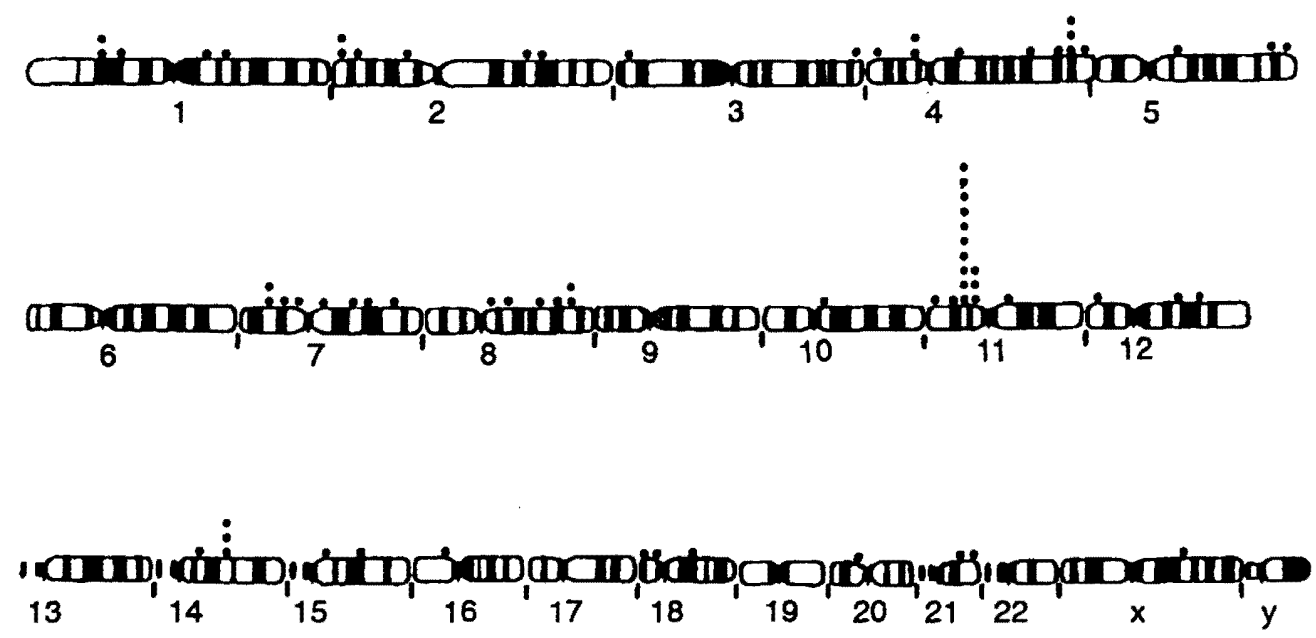

Fig. 1. Localization of RAG1 by in situ hybridization. Histogram summarizing the hybridization signal obtained with the ${ }^{3} \mathrm{H}$-labeled plasmid containing the 5-kb BamHI-SalI

with a total of 74 grains were evaluated. Thirteen grains (17.6\%) accumulated over the region 11 (p12-p13) with a dominant signal over 11 p13 (Fig. 1). Interestingly 3 of 74 grains $(4 \%)$ were observed over $14 \mathrm{q} 22$. With non-radioactive in situ hybridization, a symmetric double fluorescence signal is exclusively seen in region $11 \mathrm{p} 13$ on each of both chromosomes 11 from more than 20 metaphases analyzed (data not shown).

To position the RAG1 gene with respect to other markers and to exclude the location at chromosome 14 a panel of human-hamster somatic cell hybrids (Couillin et al. 1989; Gessler et al. 1989; Glaser et al. 1989; Luerssen et al. 1990) was analyzed with PCR (primers RAG1/1 and RAG1/2 for amplification and oligonucleotide RAG1/3 for hybridization) and Southern blots (detection of a $6-\mathrm{kb}$ human specific EcoRI fragment with the 2.5-kb EcoNIHindIII probe). Hybrid cells (V79Ly 3-2 and V79Ly 2-3) without human chromosome 11 , but retaining human chromosome 14, as well as control hamster cell line P3 show no hybridization signal in the PCR analysis (Fig. $2 A$, lanes 5-7), while human buffy coat DNA and hybrid J1-11, which contains the total short arm of human chro-

Fig. 2. A Polymerase chain reaction (PCR) analysis of $0.5-1 \mu \mathrm{g}$ genomic DNA of buffy coat (lane I), human-hamster somatic cell hybrids J1-11 (lane 2), N.W. (lane 3), M. J. (lane 4), V79Ly 3-2 (lane 5), V79Ly 3-3 (lane 6), LHVI PS (lane 8), LHV1 PH (lane 9) and a hamster control cell line P3 (lane 7). Amplification primers were RAG1/1 and RAG1/2. Ten percent of the 1,482 bp amplification product was separated on a $0.8 \%$ agarose gel, blotted to a Nytran membrane and hybridized to oligonucleotide RAG1/3. B Diagram exhibiting the position of RAG1 on chromosome I 1p13 relative to other markers. Results were obtained by PCR $(P)$ and/or Southern blotting $(S)$. The presence $(+)$ or absence $(-)$ of human RAGl is indicated below the name of each somatic cell hybrid

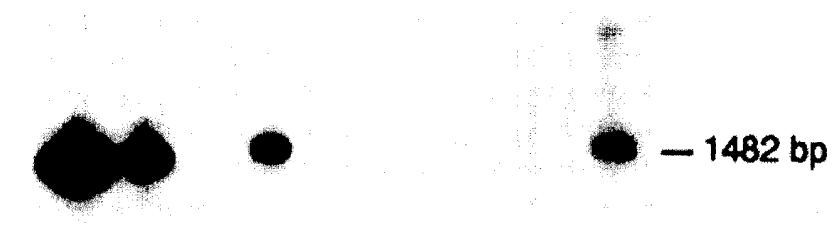

$\begin{array}{lllllllll}1 & 2 & 3 & 4 & 5 & 6 & 7 & 8 & 9\end{array}$

B

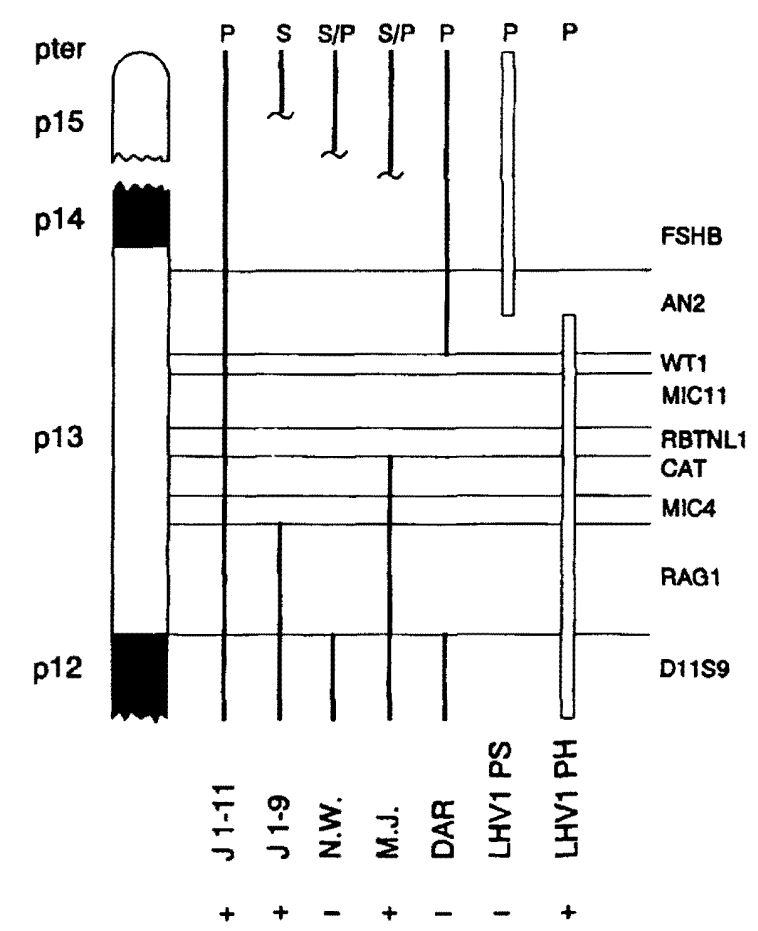


mosome 11, are positive for the 1,482-bp signal (Fig. 2A, lanes 1 and 2).

The results of the human-hamster somatic cell hybrid studies (Fig. 2B) place the RAG1 gene on human chromosome 11 between the cell surface marker MIC4 = CD44 and D11S9 and further define the centromeric breakpoints of the cell lines J1-9, DAR, N.W. and M.J.

Our analyses thus exclude chromosome 14 and confirm chromosome $11 \mathrm{p} 13$ as the location of the human RAG1 gene. Furthermore, since human RAG2 is linked to RAG1 on the basis of overlapping genomic clones (K. Schwarz, unpublished data), both genes map in this region. The RAG locus is included in a conserved linkage group that extends in the human karyotype from $11 \mathrm{p} 11-11 \mathrm{p} 13$ and is syntenic with a part of the murine chromosome 2 (Davisson et al. 1991). No known human disease maps to the RAG position on chromosome 11 , in particular, there is no observed association between immunodeficiencies and chromosome $11 \mathrm{p} 13$ abnormalities.

Acknowledgements. We thank G. Bruns, C. Jones and C. Junien for somatic cell hybrids. We appreciate the excellent technical assistance of Doris Lindner. This work was supported in part by grants from the Deutsche Forschungsgemeinschaft (DFG).

\section{References}

Blackwell TK, Alt FW (1988) Immunoglobulin genes. In: Hames BD, Glover DM (eds) Molecular immunology. IRL Press, Washington, DC, pp 61-79

Blanquet V, Turleau C, Goossens M, Besmond C (1992) Assignment of the human recombination activating gene 1 (RAG1) to the 14q21.3-q22.2 region. Genomics 13:488-489

Couillin P, Azoulay M, Henry I, Ravise N, Grisard MC, Jeanpierre C, Barichard F, Metezeau P, Candelier JJ, Lewis W, Heyningen $V$ van, Junien C (1989) Characterization of a panel of somatic cell hybrids for subregional mapping along $11 \mathrm{p}$ and within band $11 \mathrm{p} 13$. Subdivision of the WAGR complex region. Hum Genet $82: 171-178$
Davis MM (1988) T-cell antigen receptor genes. In: Hames BD, Glover DM (eds) Molecular immunology. IRL Press, Washington, DC, pp 61-79

Davisson MT, Lalley PA, Peters J, Doolittle AL, Hill RE, Favor J, Hogan BLM, Ton CCT, Saunders GF, Hanson IM, Prosser J, Jordan T, Hastie ND, Heyningen V van (1991) Mouse small eye results from mutations in a paired-like homeobox-containing gene. Nature 354:522-525

Gessler M, Thomas GH, Couillin P, Junien C, McGillivray B, Hayden J, Jaschek G, Bruns GAP (1989) A deletion map of the WAGR region on chromosome 11. Am J Hum Genet 44:486495

Glaser T, Housman D, Lewis WH, Gerhard D, Jones C (1989) A fine-structure deletion map of human chromosome 11p: analysis of the J1 series hybrids. Somat Cell Mol Genet 15:477-501

Ichihara Y, Hirai M, Kurosawa Y (1992) Sequence and chromosome assignment to $11 \mathrm{p} 13-\mathrm{p} 12$ of human RAG genes. Immunol Lett 33:277-284

Kunze N, Yang GC, Jiang ZY, Hameister H, Adolph S, Wiedorn KH, Richter A, Knippers R (1989) Localization of the active type I DNA topoisomerase gene on human chromosome 20q11.2-13.1 and two pseudogenes on chromosome lq23-24 and 22q11.2-13.1. Hum Genet 84:6-10

Lichter P, Chang Tang Ch-J, Call K, Hermanson G, Evans GA, Housman D, Ward DC (1990) High-resolution mapping of human chromosome 11 by in situ hybridization with cosmid clones. Science 247:64-69

Luerssen H, Mattei M-G, Schröter M, Grzeschik K-H, Adham IM, Engel $W(1990)$ Nucleotide sequence of the gene for human transition protein 1 and its chromosomal localization on chromosome 2. Genomics 8:324-330

Oettinger MA, Schatz DG, Gorka C, Baltimore D (1990) RAG-1 and RAG-2, adjacent genes that synergistically activate $V(D) J$ recombination. Science 248:1517-1523

Oettinger MA, Stanger B, Schatz DG, Glaser T, Call K, Housman $D$, Baltimore D (1992) The recombination activating genes, RAG1 and RAG2, are on chromosome 11p in humans and chromosome $2 \mathrm{p}$ in mice. Immunogenetics 35:97-101

Perry P, Wolff S (1974) New Giemsa method for the differential staining of sister chromatids. Nature $251: 156-158$

Saiki RK, Gelfand GH, Stoffel S, Scharf SJ, Higuchi R, Horn GT, Mullis KB, Erlich HA (1988) Primer-directed enzymatic amplification of DNA with a thermostable DNA polymerase. Science 239:487-491

Schatz DG, Oettinger MA, Baltimore D (1989) The V(D)J recombination activating gene (RAG-1). Cell 59:1035-1048 